\title{
PRINSIP KONSUMSI 4K + 1M DALAM PERSPEKTIF ISLAM
}

\author{
Muhammad Deni Putra, S.E.I., M.E \\ Fakultas Ekonomi dan Bisnis Islam IAIN Batusangkar \\ mdeniputra@iainbatusangkar.ac.id \\ Darnela Putri \\ Universitas Islam Indonesia \\ darnelaputri96@gmail.com \\ Frida Amelia, SE.Sy, M.Si \\ Fakultas Ekonomi dan Bisnis Islam IAIN Batusangkar \\ fridaamelia.19@gmail.com
}

\begin{abstract}
Since humans know their social life, a problem that must be solved together grows, namely how every human being meets their individual needs. Islam is a religion whose teachings regulate all human behavior in meeting their needs. Consumption is a form of economic expression that is basic in the needs of human life.

The purpose of this article is to analyze how the principle of consumption of $4 \mathrm{~K}+1 \mathrm{M}$ from an Islamic perspective. This article uses the hermeneutic approach. In simple terms, hermeneutics can be understood as the art of interpreting or understanding, ie, clarifying the problem of knowledge by investigating every detail of the interpretation process. The hermeneutic approach is beneficial, especially in exploring and interpreting the principles of the Qur'an and the Hadith regarding the policy of Muslim consumption in the current reality. To support the hermeneutic approach, the semantic method is used. This method is needed, especially in analyzing key words referred to in this study.

This article concludes that Islam is a religion whose teachings regulate all human behavior in meeting their needs, one of which is consumption. In Islam, consumption is controlled by five basic principles that can be used as a fundamental statement by a person/group as a guide for thinking or acting. The $4 K+1 M$ consumption principle is the principle of justice, the law of cleanliness, the policy of simplicity, the principle of generosity, and the faith of morality.
\end{abstract}

Keywords: Principles, $4 K+1 M$, Consumption of Islamic Perspectives 


\section{Abstrak}

Sejak manusia mengenal hidup bergaul, tumbuhlah suatu masalah yang harus dipecahkan bersama-sama, yaitu bagaimana setiap manusia memenuhi kebutuhan mereka masing-masing. Islam adalah agama yang ajarannya mengatur segenap prilaku manusia dalam memenuhi kebutuhan hidupnya. Konsumsi adalah suatu bentuk perilaku ekonomi yang asasi dalam kebutuhan hidup manusia.

Tujuan dari artikel ini adalah untuk menganalisis bagaimana prinsip konsumsi $4 \mathrm{~K}+1 \mathrm{M}$ dalam perspektif Islam. Artikel ini menggunakan pendekatan hermeneutik. Secara sederhana hermeneutik dapat dipahami sebagai seni menafsirkan atau memahami, yaitu menjernihkan persoalan mengerti dengan cara menyelidiki setiap detail proses interpretasi. Pendekatan hermeneutik sangat berguna terutama dalam mengeksplorasi dan menafsirkan prinsipprinsip Al-Qur'an dan Hadis mengenai prinsip konsumsi muslim dalam realitas yang dihadapi sekarang. Untuk mendukung pendekatan hermeneutik digunakan metode semantik. Metode ini diperlukan terutama dalam menganalis kata-kata kunci yang dimaksud dalam penelitian ini.

Artikel ini menyimpulkan bahwa Islam adalah agama yang ajarannya mengatur segenap prilaku manusia dalam memenuhi kebutuhan hidupnya salah satunya adalah konsumsi. Dalam Islam konsumsi dikendalikan oleh lima prinsip dasar yang dapat dijadikan suatu pernyataan fundamental oleh seseorang/ kelompok sebagai pedoman untuk berpikir atau bertindak. Prinsip konsumsi $4 \mathrm{~K}+1 \mathrm{M}$ tersebut adalah prinsip keadilan, prinsip kebersihan, prinsip kesederhanaan, prinsip kemurahan hati dan prinsip moralitas.

Kata Kunci: Prinsip, 4k+1M, Konsumsi Perspektif Islam

\section{Pendahuluan}

Sejak manusia mengenal hidup bergaul, tumbuhlah suatu masalah yang harus dipecahkan bersama-sama, yaitu bagaimana setiap manusia memenuhi kebutuhan mereka masing-masing, karena kebutuhan seseorang tidak mungkin dapat dipenuhi oleh dirinya sendiri. Makin luas pergaulan mereka, makin bertambah kuatlah ketergantungan antara satu sama yang lain untuk memenuhi kebutuhan itu. ${ }^{1}$ Kebutuhan manusia banyak ragamnya dan memiliki tingkatan-tingkatan yang secara umum terbagi tiga, yaitu kebutuhan

\footnotetext{
${ }^{1}$ Aulia Rahman dan Muh Fitrah, "Perilaku Konsumsi Masyarakat Dalam Perspektif Islam Di Kelurahan Barombong Kota Makassar", Laa Maisyir: Jurnal Ekonomi Islam 5.1 (2018). hlm. 19.
} 
primer (daruriyyat), sekunder (hajiyyat), dan tertier (tahsiniyyat). Kebutuhan yang menduduki peringkat kedua dan ketiga tidak sama pada setiap orang, akan tetapi kebutuhan primer manusia sejak dahulu hingga sekarang menurut M. Quraish Shihab dapat dikatakan sama, yaitu kebutuhan pangan, sandang, dan papan. ${ }^{2}$

Islam dalam hal konsumsi melarang suka akan bermewah-mewahan dan berlebih-lebihan, tapi mempertahankan keseimbangan yang adil. Penelitian yang dilakukan oleh Ernawati dan Ritta Setiyati yang berjudul Wawasan Qur'an Tentang Ekonomi (Tinjauan Studi Penafsiran Tematik Al-quran) menyimpulkan bahwa ${ }^{3} \mathrm{Al}$ Qur'an memberi arahan dan ketetapan yang sangat unggul, lengkap dan mendasar terkait ekonomi untuk dipahami dan dilaksanakan oleh segenap manusia. Jika ketentuan tersebut ditaati dengan penuh keimanan dan konsistensi maka akan tercapai kesejahteraan dan kebahagian hidup ummat manusia di dunia maupun di akhirat.

Selanjutnya, penelitian yang dilakukan oleh Zamakhsyari Abdul Majid yang berjudul Ekonomi Dalam Perspektif Alquran memberikan kesimpulan bahwa $^{4}$ (1) Pemilik harta yang hakiki adalah Allah Swt. Namun demikian Alquran juga memberi pengakuan terhadap hak milik pribadi dengan segala keterbatasannya. (2) Hukum asal mencari harta adalah ibâhah (boleh) selama dijalankan dengan usaha-usaha yang baik dan halal. (3) Dalam kedudukan manusia sebagai musta'mir, ia wajib mengolah dan mengelola bumi ini dengan sebaikbaiknya. Alam adalah harta kekayaan produktif yangtidak dibenarkan untuk ditelantarkan. (4) Salah satu prinsip dasar ekonomi Islam adalah asas keseimbangan yang bermuara kepada sikap hidup sederhana, tidak berlebihan dan tidak terlalu kikir.

\footnotetext{
${ }^{2}$ Isnaini Harahap, dkk. Hadis Hadis Ekonomi, (Jakarta: Kharisma Putra Utama, 2015), hlm. 149.

${ }^{3}$ Ernawati, Ritta Setiyati, “ Wawasan Qur'an Tentang Ekonomi (Tinjauan Studi Penafsiran Tematik Al-Quran)" Jurnal Ekonomi Volume 8 Nomor 2, November 2017 . hlm. 51.

"Zamakhsyari Abdul Majid, "Ekonomi Dalam Perspektif Alquran”, Ahkam: Vol. XVI, No. 2, Juli 2016, hlm. 259.
} 
Seorang muslim harus memperhatikan prinsip-prinsip konsumsi Islam. ${ }^{5}$ Penelitian yang dilakukan oleh Aulia Rahman dan Muh Fitrah yang berjudul Perilaku Konsumsi Masyarakat Dalam Perspektif Islam Di Kelurahan Barombong Kota Makassar memberikan kesimpulan bahwa6 Perilaku konsumsi masyarakat di Kelurahan Barombong Kota Makassar tingkat ekonomi atas, sepenuhnya belum baik sebagian masyarakat masih berperilaku yang tidak sesuai dengan Islam, yaitu perilaku tabzir. Perilaku konsumsi masyarakat di Kelurahan Barombong Kota Makassar tingkat ekonomi menengah dan tingkat ekonomi rendah sudah baik karena sudah mengkonsumsi sesuai etika dan prinsip konsusmsi dalam Islam.

Berdasarkan latar belakang di atas, Artikel ini berupaya mencari bagaimana prinsip konsumsi dalam perspektif Islam yang ditinjau dari AlQur'an dan Hadis, yaitu prinsip konsumsi yang mengedepankan nilai-nilai keislaman yang dirumuskan sebagai konsep prinsip konsumsi $4 \mathrm{~K}+1 \mathrm{M}$ dalam perspektif Islam.

\section{Metode Penafsiran}

Artikel ini menggunakan penafsiran kitab tafsir Al-Misbah karya M. Quraish Shihab dengan pendekatan hermeneutik yang didukung oleh metode semantik. Artikel ini menggunakan metode penafsiran yang relevan untuk menjawab permasalahan yang dirumuskan. ${ }^{7}$

Lebih khusus, artikel ini mendasarkan diri pada ayat-ayat Al-Qur'an, maka akan menggunakan pendekatan hermeneutik. Secara sederhana hermeneutik dapat dipahami sebagai seni menafsirkan atau memahami, yaitu menjernihkan persoalan mengerti dengan cara menyelidiki setiap detail proses

${ }^{5}$ Aulia Rahman. Muh Fitrah, "Perilaku..., hlm. 19.

${ }^{6}$ Aulia Rahman Dan Muh Fitrah, "Perilaku..., hlm. 40.

${ }^{7}$ Lukman Fauroni, Etika Bisnis Dalam Al-Qur'an, (Yogyakarta: Pustaka Pesantren, 2006), hlm 19-20. 
interpretasi. ${ }^{8}$ Pendekatan hermeneutik sangat berguna terutama dalam mengeksplorasi dan menafsirkan prinsip-prinsip Al-Qur'an dan Hadis mengenai prinsip konsumsi muslim dalam realitas yang dihadapi sekarang. Untuk mendukung pendekatan hermeneutik akan digunakan metode semantik. Metode ini diperlukan terutama dalam menganalis kata-kata kunci yang dimaksud dalam penelitian ini. ${ }^{9}$ Adapun kata kunci dari artikel ini adalah Prinsip, 4K+1M, Konsumsi Perspektif Islam.

\section{Komsumsi Perspektif Islam}

Islam telah mengatur jalan hidup manusia melalui firmanNya yaitu alQurean dan Hadits Nabi Muhammad Saw agar manusia dijauhkan dari sifatsifat yang hina karena perilaku konsumsinya. Konsumsi Muslim dalam Ekonomi Islam bahwa seorang muslim dalam berkonsumsi didasarkan atas pertimbangan manusia tidak kuasa sepenuhnya mengatur detail permasalahan ekonomi masyarakat atau negara. Terselenggaranya keberlangsungan hidup manusia diatur oleh Allah. ${ }^{10}$

Konsumsi adalah suatu bentuk perilaku ekonomi yang asasi dalam kehidupan manusia. Setiap makhluk hidup pasti melakukan aktivitas konsumsi termasuk manusia. ${ }^{11}$ Konsumsi dalam arti ekonomi adalah semua penggunaan barang dan jasa yang dilakukan manusia untuk memenuhi kebutuhan hidupnya, dan tujuan manusia mengkonsumsi adalah agar memperoleh kepuasan setinggi-tingginya dan mencapai tingkat kemakmuran dalam arti terpenuhinya berbagai macam keperluan baik kebutuhan pokok, sekunder, barang mewah, maupun kebutuhan jasmani dan kebutuhan rohani. ${ }^{12}$

\footnotetext{
${ }^{8}$ Lukman Fauroni, Etika..., hlm. 20.

${ }^{9}$ Lukman Fauroni, Etika..., hlm. 21.

${ }^{10}$ Aulia Rahman Dan Muh Fitrah, "Perilaku..., hlm. 26-27.

${ }^{11}$ Rahmat Ilyas, "Etika Konsumsi Dan Kesejahteraan Dalam Perspektif Ekonomi Islam”, AtTawassuth, Vol. 1, No. 1, 2016, hlm. 152.

${ }^{12}$ Aulia Rahman Dan Muh Fitrah, "Perilaku..., hlm. 21.
} 
Islam adalah agama yang ajarannya mengatur segenap prilaku manusia dalam memenuhi kebutuhan hidupnya. Demikian pula dalam masalah konsumsi, Islam mengatur bagaimana manusia dapat melakukan kegiatankegiatan konsumsi yang membawa manusia berguna bagi kemashlahatan hidupnya. Seluruh aturan Islam mengenai aktivitas konsumsi terdapat dalam al-Qur'an dan as-Sunnah. Prilaku konsumsi yang sesuai dengan ketentuan alQur'an dan as-Sunnah ini akan membawa pelakunya mencapai keberkahan dan kesejahteraan hidupnya. ${ }^{13}$

Islam memandang bahwa bumi dengan segala isinya merupakan amanah Allah SWT kepada sang Khalifah agar dipergunakan sebaik-baiknya bagi kesejahteraan bersama. Dalam satu pemanfaatan yang telah diberikan kepada sang Khalifah adalah kegiatan ekonomi (umum) dan lebih sempit lagi kegiatan konsumsi (khusus). Islam mengajarkan kepada sang khalifah untuk memakai dasar yang benar agar mendapatkan keridhaan dari Allah Sang Pencipta. ${ }^{14}$

\section{Prinsip Perilaku Konsumsi Dalam Perspektif Islam}

Perilaku konsumsi dalam kajian ekonomi Islam mempunyai karakteristik perbedaan standar perilaku yang khas. Secara ideal setiap perilaku muslim, termasuk dalam perilaku konsumsi harus mempunyai pijakan dari sumber ajaran al-Qurean dan Hadis yang harus dikembangkan dari kedua sumber ajaran tersebut. ${ }^{15}$ Perilaku konsumsi seorang muslim tidak hanya sekedar untuk memenuhi kebutuhan jasmani, tetapi juga untuk memenuhi kebutuhan rohani. Sehingga dalam perilaku konsumsi seorang muslim senantiasa memperhatikan syariat Islam. Misalnya, apakah barang dan

\footnotetext{
${ }^{13}$ Abdul Hamid, “Teori Konsumsi Islam Dalam Peningkatan Ekonomi Umat”, J-Ebis Vol. 3 No. 2 Juni 2018, hlm. 206.

${ }^{14}$ Ibid.

${ }^{15}$ Lukman Fauroni, Tafsir Ayat-Ayat Tentang Konsumsi (Aplikasi Tafsir Ekonomi Al-Qur'an), hlm. 2 .
} 
jasa yang dikonsumsi halal atau haram, apa tujuan seorang muslim melakukan aktivitas konsumsi, bagaimana etika dan moral seorang muslim dalam berkonsumsi, bagaimana bentuk perilaku konsumsi seorang muslim dikaitkan dengan keadaan lingkungannya. ${ }^{16}$

Prinsip adalah suatu pernyataan fundamental atau kebenaran umum maupun individual yang dijadikan oleh seseorang/ kelompok sebagai sebuah pedoman untuk berpikir atau bertindak. sebuah prinsip merupakan roh dari sebuah perkembangan ataupun perubahan, dan merupakan akumulasi dari pengalaman oleh sebuah obyek atau subyek tertentu. ${ }^{17}$ Ada beberapa prinsip dalam berkonsumsi bagi seorang muslim yang membedakannya dengan perilaku konsumsi non muslim. Prinsip tersebut didasarkan pada ayat-ayat alQur'an dan hadis Nabi Muhammad Saw. ${ }^{18}$

Perilaku secara terminologi adalah kegiatan atau aktivitas organisme (makhluk hidup) yang bersangkutan, sehingga yang dimaksud dengan perilaku manusia pada hakikatnya adalah tindakan atau aktivitas manusia itu sendiri, baik yang dapat diamati secara langsung maupun yang tidak dapat diamati oleh pihak luar dan mempunyai bentangan yang sangat luas, antara lain berjalan, berbicara, menangis dan bekerja. ${ }^{19}$

Perilaku konsumsi yang dikenal dalam istilah bahasa Inggris consumtion behavior makin penting keberadaannya setelah ekonom Inggris John Mynar Lord Kynes memperkenalkan teorinya yang dikenal dengan istilah Low of Consumtion (Hukum Konsumsi) yang belakangan mengilhami para penulis ilmu ekonomi mempopulerkan istilah perilaku konsumen dalam tulisan mereka. ${ }^{20}$

\footnotetext{
${ }^{16}$ Rahmat Ilyas, "Etika..., hlm. 162.

${ }^{17}$ https://id.wikipedia.org/wiki/Prinsip diakses pada hari Jum'at tanggal 5 April 2019 jam 15;30 WIB.

${ }^{18}$ Aulia Rahman Dan Muh Fitrah, "Perilaku..., hlm. 23.

${ }^{19}$ Isnaini Harahap, dkk. Hadis Hadis Ekonomi, ( Jakarta: Kharisma Putra Utama, 2015), hlm. 155.

${ }^{20}$ Rahmat Ilyas, “Etika..., hlm. 161.
} 
Manusia hidup dengan segenap potensi alamiah. Termasuk adanya kebutuhan yang ada pada setiap manusia. Kebutuhan adalah keinginan manusia baik yang berupa barang atau jasa yang dapat memberikan kepuasan bagi jasmani atau rohani untuk kelangsungan hidup manusia. ${ }^{21}$ Kebutuhan tersebut dapat memotivasi manusia bertindak memenuhi kebutuhannya salah satunya melakukan aktivitas konsumsi.

Konsumsi yang berlebih-lebihan tidak diperbolehkan dalam Islam dan disebut dengan Israf (pemborosan) atau tabzir (menghambur-hamburkan harta tanpa guna). Tabzir berarti mempergunakan harta dalam cara yang sala, yaitu menuju tujuan-tujuan terlarang, seperti penyuapan, hal-hal yang melanggar hukum atau dengan cara tanpa aturan. Pemborosan berarti penggunaan harta secara berlebih-lebihan untuk hal-hal yang melanggar hukum dalam hal seperti makanan, pakaian, tempat tinggal. Ajaran-ajaran Islam menganjurkan pola konsumsi dan penggunaan harta secara wajar dan berimbang. ${ }^{22}$

Aturan dan kaedah berkonsumsi dalam sistem ekonomi Islam mengatur keseimbangan dalam berbagai aspek. Konsumsi yang dijalankan oleh seseorang muslim tidak boleh mengorbankan kemeslahatan individu dan masyarakat. Bahkan sikap ekstrim pun haris dijauhkan dalam berkonsumsi. ${ }^{23}$ Ekonomi Islam diarahkan untuk mewujudkan tujuan syariah (Maqoshid Syariah) yaitu pemenuhan kebutuhan, penghasilan yang diperoleh dengan sumber yang baik, distribusi pendapatan dan kekayaan yang adil serta pertumbuhan dan stabilitas ekonomi. $^{24}$ Dalam ekonomi Islam konsumsi dikendalikan oleh lima prinsip dasar diantaranya adalah sebagai berikut:

\footnotetext{
${ }^{21}$ Rahmat Ilyas, “Etika..., hlm. 154.

${ }^{22}$ Vinna Sri Yuniarti, Ekonomi Mikro Syariah, (Bandung: CV Pustaka Setia, 2016), hlm.83-84.

${ }^{23}$ Abdul Hamid, "Teori Konsumsi Islam Dalam Peningkatan Ekonomi Umat”, J-Ebis Vol. 3 No. 2 Juni 2018, hlm. 214.

${ }^{24}$ Ernawati, Ritta Setiyati, “Wawasan..., hlm.55.
} 


\section{Prinsip Keadilan}

Dalam berkonsumsi, harta yang digunakan haruslah didapatkan dengan jalan keadilan yang berarti tidak mengandung unsur kedzaliman. Tidak dengan harta orang lain yang diperoleh melalui jalan kebathilan. Allah berfirman dalam surat Al-Baqarah Ayat 188.

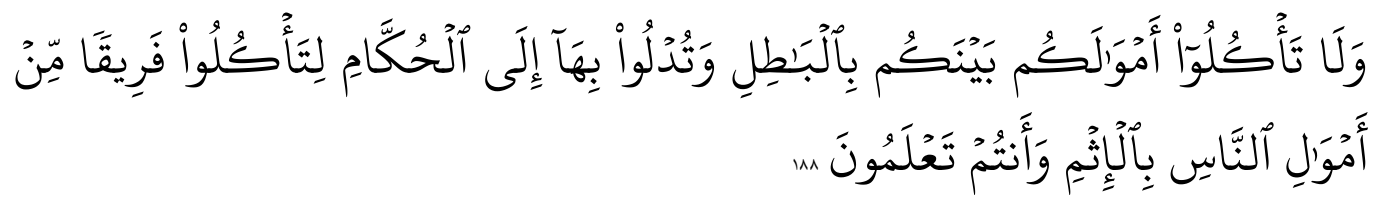

"Dan janganlah sebahagian kamu memakan harta sebahagian yang lain di antara kamu dengan jalan yang bathil dan (janganlah) kamu membawa (urusan) harta itu kepada hakim, supaya kamu dapat memakan sebahagian daripada harta benda orang lain itu dengan (jalan berbuat) dosa, padahal kamu mengetahui."

Pengembangan harta tidak dapat terjadi kecuali dengan interaksi antara manusia dengan manusia lain, dalam bentuk pertukaran dan bantu-membantu. Makna-makna inilah yang antara lain dikandung oleh penggunaan kata bainakum/antara kamu dalam firmanNya yang memulai uraian menyangkut perolehan harta. Kata antara mengisyaratkan juga bahwa interaksi dalam perolehan harta terjadi antara dua pihak. Keuntungan atau kerugian dari transaksi itu, tidak boleh ditarik terlalu jauh oleh masing-masing, sehingga salah satu pihak merugi, sedangkan pihak lain mendapatkan keuntungan, sehingga bila demikian harta tidak lagi berada ditengah atau antara, dan kedudukan kedua pihak tidak lagi seimbang. Perolehan yang tidak seimbang adalah batil, dan yang batil adalah segala sesuatu yang tidak hak, tidak dibenarkan oleh hukum serta tidak sejalan dengan tuntunan ilahi walaupun dilakukan atas dasar kerelaan yang berinteraksi. ${ }^{25}$

${ }^{25} \mathrm{M}$ Quraisy Shihab, Tafsir Al-Misbah Pesan, Kesan dan Keserasian al-Qur'an, (Jakarta: Lentera Hati, 2002) volume 1. hlm 414. 
Ulama memahami penutup ayat ini sebagai isyarat tentang bolehnya memberi sesuatu kepada yang berwenang bila pemberian itu tidak bertujuan dosa, tetapi bertujuan mengambil hak pemberi sendiri. Ayat di atas juga dapat bermakna, janganlah sebagian kamu mengambil harta orang lain dan menguasainya tanpa hak, dan jangan pula menyerahkan urusan harta kepada hakim yang berwenang memutuskan perkara bukan tujuan untuk memperoleh hak kalian, tetapi untuk mengambil hak orang lain dengan melakukann dosa, dan dalam keadaan mengetahui bahwa kalian sebenarnya tidak berhak. ${ }^{26}$

\section{Prinsip Kebersihan}

Prinsip yang kedua ini tercantum dalam kitab suci Al-Qurean maupun Sunnah tentang makanan. Harus baik atau cocok untuk dimakan, tidak kotor ataupun menjijikkan sehingga merusak selera. Karena itu, tidak semua yang diperkenankan boleh dimakan dan diminum dalam semua keadaan. Dari semua yang diperbolehkan makan dan minumlah yang bersih dan bermanfaat.

Dalam soal makanan dan minuman, yang terlarang adalah darah, daging binatang yang telah mati sendiri, daging babi, daging binatang yang ketika disembelih diserukan nama selain Allah, sebagaimana firman Allah dalam surat Al-Baqarah ayat 173.

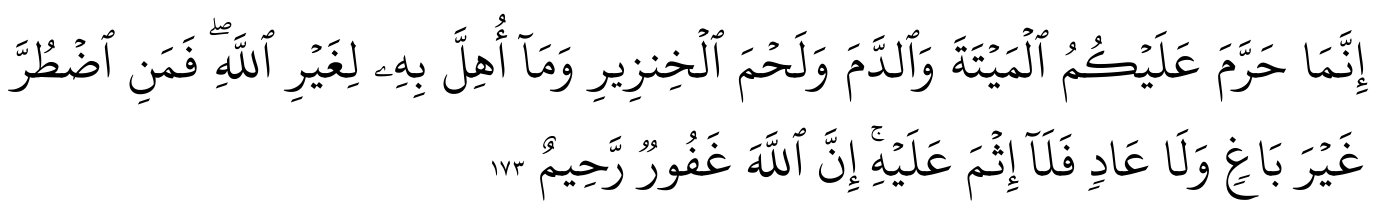

"Sesungguhnya Allah hanya mengharamkan bagimu bangkai, darah, daging babi dan binatang yang (ketika disembelih) disebut (nama) selain Allah. Tetapi barang siapa dalam keadaan terpaksa (memakannya) sedang ia tidak

${ }^{26}$ M Quraisy Shihab, Tafsir..., hlm. 414-415. 
menginginkannya dan tidak (pula) melampaui batas, maka tidak ada dosa baginya. Sesungguhnya Allah Maha Pengampun lagi Maha Penyayang."

Yang dimaksud bangkai adalah binatang yang berhembus nyawanya tidak melalui cara yang sah, seperti yang mati tercekik, dipukul, jatuh, ditanduk, dan diterkam binatang buas, namun tidak sempat disemblih, dan (yang disemblih untuk berhala). Dikecualikan dari pengertian bangkai adalah binatang air (ikan dan sebagainya) dan belalang. ${ }^{27}$

Darah, yakni darah yang mengalir bukan untuk substansi awalnya membeku seperti limpah dan hati. Daging babi, yakni seluruh tubuh babi, termasuk tulang, lemak, dan kulitnya. ${ }^{28}$

Binatang yang ketika disembelih disebut nama selain Allah, artinya bahwa binatang semacam itu baru haram dimakan bila disembelih dalam keadaan menyebut selain nama Allah. Adapun bila tidak disebut namaNya, maka binatang halal yang disemblih demikian, masih dapat ditoleransi untuk dimakan. ${ }^{29}$

Kasih sayang Allah melimpah kepada makhluk, karena itu Dia selalu menghendaki kemudahan buat manusia. Dia tidak menetapkan sesuatu yang menyulitkan manusia. Penjelasan tentang makanan yang diharamkan di atas, dikemukakan dalam konteks mencela masyarakat Jahiliah, baik di Mekah maupun di Madinah, yang memakannya. Mereka misalnya membolehkan memakan bintang yang mati tanpa disembelih dengan alasan bahwa yang disembelih nyawanya oleh manusia halal, maka mengapa haram yang dicabut sendiri nyawanya oleh Allah?. ${ }^{30}$

\footnotetext{
${ }^{27}$ M Quraisy Shihab, Tafsir..., hlm. 385.

${ }^{28}$ Ibid.

${ }^{29}$ Ibid.

${ }^{30}$ Ibid. hlm. 385-386.
} 


\section{Prinsip Kesederhanaan}

Sederhana merupakan sikap bersahaja dan bisa disebut bahwa sederhana juga merupakan sikap tidak berlebih-lebihan atau secukupnya. Sederhana merupakan aplikasi dari kehidupan sehari-hari salah satunya dalam hal berkonsumsi. "Berlebih-lebihan" secara konkret dalam bentuk pembelanjaan harta untuk hal-hal yang diharamkan, seperti khamr, narkoba, bejana-bejana emas, perak dan sejenisnya, sedikit ataupun banyak. ${ }^{31}$ "Diriwayatkan dari Ummu Salamah, istri Nabi Muhammad SAW, bahwa Rasulullah SAW bersabda, 'Orang yang minum dari tempat minum yang terbuat dari perak sebenarnya telah menyalakan api neraka di dalam perutnya."

Selanjutnya, tidak boros merupakan salah satu sikap pokok dalam konsumsi. Konsumsi yang berlebihan adalah perbuatan keji karena termasuk pemborosan. "Dari Amr bin Sya'ab dari bapaknya dari kakeknya ia berkata: Rasulullah SAW bersabda: 'Makanlah, minumlah, berpakaianlah, dan bersedekahlah dengan tidak berlebih-lebihan dan menyombongkan diri." (HR. Abu Daud dan Ahmad). ${ }^{32}$

Islam mengingatkan manusia agar tidak terlena dalam kehidupan yang materialistis dan hedonistis. Hal ini bukan berarti bahwa Islam melarang manusia untuk menikmati kehidupan di dunia. Allah memberikan manusia berbagai kenikmatan yang menunjang kehidupan manusia yang dinamis, berupa pakaian, minuman, makanan, perumahan, kendaraan, alat komunikasi, alat rumah tangga, dan sebagainya.

Manusia hanya diingatkan untuk bersikap sewajarnya dan tidak melampaui batas-batas agar dapat dipertanggungjawabkan sehingga

\footnotetext{
${ }^{31}$ Yusuf Qardawi, Halal Haram Dalam Islam, (Solo: Pt Era Adicitra Intermedia, 2011), hlm. 468.

${ }^{32}$ Isnaini Harahap, dkk. Hadis.., hlm. 151.
} 
tidak menimbulkan bahaya bagi kesejahteraan masyarakat umum akibat dari pengeluaran yang berlebih-lebihan dan hanya menuruti hawa nafsu. ${ }^{33}$ Ajaran agama yang dijalankan baik menghindarkan konsumen dari sifat israf, karena israf merupakan sifat boros yang dengan sadar dilakukan untuk memenuhi tuntutan nafsu belaka. ${ }^{34}$

Prinsip kesederhanaan intinya adalah mengatur manusia dalam aktivitas konsumsi dengan sikap yang sederhana alias tidak berlebihlebihan, seperti firman Allah SWT dalam surat Al- A'raf Ayat 31.

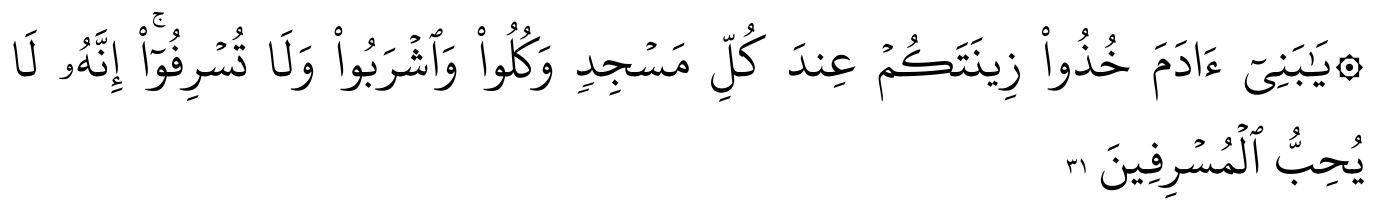

"Hai anak Adam, pakailah pakaianmu yang indah di setiap (memasuki) mesjid, makan dan minumlah, dan janganlah berlebih-lebihan. Sesungguhnya Allah tidak menyukai orang-orang yang berlebih-lebihan."

Ayat ini mengajak manusia untuk memakai pakaian yang indah, minimal dalam bentuk menutup aurat dan lakukan setiap memasuki masjid. Dan makanlah makanan yang halal, enak, bermanfaat, lagi bergizi, berdampak baik serta minumlah apa saja yang kamu sukai selagi tidak memabukan, tidak juga menggangu kesehatan dengan cara tidak berlebih-lebihan dalam segala hal, baik dalam beribadah dengan menambah cara atau kadarnya begitu juga dengan dalam hal makan dan minum atau apa saja, sesungguhnya Allah tidak menyukai, yakni tidak melimpahkan rahmat dan ganjaran bagi orang-orang yang berlebihan dalam hal apapun. ${ }^{35}$

\footnotetext{
${ }^{33}$ Afzalur Rahman, Doktrin Ekonomi Islam Jilid II, (Yogyakarta: PT. Verisia Yogya Grafika, 1995), hlm. 51.

${ }^{34}$ Rahmat Ilyas, "Etika..., hlm. 152.

${ }^{35} \mathrm{M}$ Quraisy Shihab, Tafsir Al-Misbah Pesan, Kesan dan Keserasian al-Qur'an, (Jakarta: Lentera Hati, 2002) volume 5. hlm 75.
} 
Perintah makan dan minum, lagi tidak berlebih-lebihan, yakni tidak melampaui batas, merupakan tuntunan yang harus disesuaikan dengan kondisi setiap orang. Ini karena kadar tertentu yang dinilai cukup untuk seseorang, boleh jadi telah dinilai melampaui batas atau belum cukup buat orang lain. Atas dasar itu, kita dapat berkata bahwa penggalan ayat tersebut mengajarkan sikap proposional dalam makan dan minum. ${ }^{36}$

Dari Miqdam Ibnu Ma'dikarib sesungguhnya Rasulullah SAW bersabda: Tidak ada wadah yang dipenuhkan manusia lebih buruk dari perut. Cukuplah bagi anak adam beberapa suap yang dapat menegakkan tulang punggungnya, jikapun ingin berbuat lebih, maka sepertiga untuk makanan dan sepertiga untuk minum dan sepertiga lagi untuk nafasnya. (HR. Tirmidzi dan Ibnu Hibban). ${ }^{37}$

Rasulullah Muhammad saw, ketika ditanya oleh malaikat Jibril apakah beliau ingin agar gunung-gunung batu di Makkah berubah menjadi gunung emas, maka beliau menolaknya dan lebih suka beliau dengan keadaan apa adanya, yaitu sehari dapat kenyang dan sehari lapar. Ketika kenyang maka dapat beryukur kepada Allah dan ketika lapar maka bisa bersabar dengan selalu berendah diri mengharap kasih sayang Allah. Beliau juga menyampaikan tentang larangan menggunakan piring emas dan cangkir emas untuk digunakan sebagai peralatan makan dan minum, demikian pula larangan memakai pakaian sutera bagi kaum laki- laki, yang semuanya itu akan digunakan untuk para penghuni surga kelak di akhirat. ${ }^{38}$

\footnotetext{
${ }^{36}$ Ibid. hlm. 76.

${ }^{37} \mathrm{Ibid}$.

${ }^{38}$ Abdul Hamid, "Teori..., hlm.213.
} 


\section{Prinsip Kemurahan Hati}

Dengan mentaati perintah Islam tidak ada bahaya maupun dosa ketika kita memakan dan meminum makanan halal yang disediakan Tuhan karena kemurahan hati-Nya. Selama maksudnya adalah untuk kelangsungan hidup dan kesehatan yang lebih baik dengan tujuan menunaikan perintah Tuhan dengan keimanan yang kuat dalam tuntutan-Nya, dan perbuatan adil sesuai dengan itu, yang menjamin persesuaian bagi semua perintah-Nya.

Keberhasilan dalam Islam diukur dengan keridhaan Allah. Segala perbuatan yang dilakukan harus selaras dan tidak bertentangan dengan apa-apa yang ditetapkan Allah. kekayaan, tenaga, waktu dan semuanya tidak digunakan untuk kepentingan sendiri. tetapi juga untuk kegiatan sosial seperti zakat, infak, dan sedekah. Itulah kenapa Islam memotivasi umatnya untuk menyalurkan sebagian rejekinya. ${ }^{39}$

“Diriwayatkan dari Abdullah bin Umar bahwa Rasulullah SAW bersabda, sedang Beliau berada diatas mimbar. Beliau menyebutkan tentang sedekah dan menjauhi perbuatan meminta-minta, karena tangan diatas lebih baik dari tangan di bawah. Tangan diatas adalah yan memberi dan tangan di bawah adalah yang menerima." 40 Allah berfirman dalam Surat Saba' (34) ayat 39 yaitu:

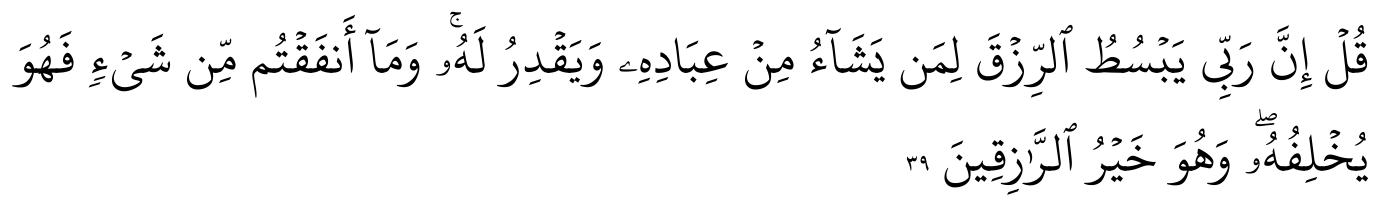

"Katakanlah: "Sesungguhnya Tuhanku melapangkan rezeki bagi siapa yang dikehendaki-Nya di antara hamba-hamba-Nya dan menyempitkan bagi (siapa yang dikehendaki-Nya)". Dan barang apa saja yang kamu nafkahkan, maka Allah akan menggantinya dan Dialah Pemberi rezeki yang sebaik-baiknya".

${ }^{39}$ Isnaini Harahap, dkk. Hadis.., hlm. 154.

${ }^{40}$ Ibid. 
Ayat di atas menyatakan: katakanlah wahai Nabi Muhammad kepada siapa yang menduga bahwa rezeki dianugerahkan Allah atas dasar cinta dan murkaNya atau ia diperoleh berkat usaha dan kepandaian seseorang semata-mata katakanlah bahwa: "Sesungguhnya Tuhanku melapangkan rezeki dari saat ke saat bagi siapa yang dikehendakiNya di antara hamba-hamba-Nya serta pada waktu yang ditetapkanNya dan menyempitkan pula baginya dalam batas dan waktu yang dikehendakiNya. Seandainya perolehan rezeki disebabkan karena Allah suka atau tidak terhadap seseorang atau berdasar usaha dan kepandaian seseorang, niscaya tidak akan terjadi perbedaan dalam perolehan rezeki bagi seseorang. ${ }^{41}$

Demikian Allah mengatur dan menetapkan perolehan rezeki semata-mata karena kebijaksanaanNya dan karena itu tidak perlu risau dan bersifat kikir dalam menafkahkannya. Allah akan mengantinya di dunia atau di akhirat, penggantian yang serupa atau lebih baik darinya. Itu pun berdasar kehendakNya. Dialah Yang Maha Kaya dan Dialah Pemberi rezeki yang sebaik-baiknya. ${ }^{42}$

Ayat ini dinilai juga mengandung bantahan tentang pandangan negatif kaum musyrikin terhadap kaum muslimin. Ia bagaikan menyatakan bahwa tidak semua kaum beriman sempit rezekinya. Ada diantara mereka yang kaya/berkecukupan. Memang ada juga yang sempit rezekinya, tetapi itu bukanlah sesuatu yang negatif buat mereka jika mereka konsisten mengikuti tuntunan ilahi. Sementara ulama mengingatkan bahwa ayat ini bukan berarti jaminan perolehan ganti rezeki yang dinafkahkan akan diberi dalam kehidupan dunia ini. Karena

${ }^{41}$ M Quraisy Shihab, Tafsir Al-Misbah Pesan, Kesan dan Keserasian al-Qur'an, (Jakarta: Lentera Hati, 2002) volume 11. hlm 398.

${ }^{42}$ Ibid. 
itu hendaklah setiap orang berhemat dengan rezeki yang ditangannya, tidak memboroskannya. ${ }^{43}$

Menurut pandangan Islam, harta kekayaan bahkan segala sesuatu adalah milik Allah. Namun demikian diakui pula bahwa potensi manusia dalam mengolah bahan mentah hasil bumi yang telah disiapkan Allah tidak dipungkiri adanya. Hanya saja dalam melaksanakan segala aktivitas itu manusia harus bekerja sama dengan individu lainnya guna keberhasilan usahanya. Maka wajar bila Allah memerintahkan manusia untuk menyisihkan sebagian hartanya untuk kepentingan orang banyak. Mencari, mengumpulkan dan memiliki harta kekayaan tidaklah dilarang selama ia diakui sebagai karunia dan amanah Allah Swt. Alquran tidak menentang kepemilikan harta sebanyak mungkin, bahkan Alquran secara tegas dan berulang-ulang memerintahkan agar berupaya sungguh-sungguh dalam mencari rezeki yang diiistilahkan Alquran dengan "fadhl Allâh" (limpahan karunia Allah). ${ }^{44}$

\section{Prinsip Moralitas}

Peningkatan atau kemajuan nilai-nilai moral dan spiritual seseorang muslim diajarkan untuk menyebut nama Allah sebelum makan dan menyatakan terima kasih kepada-Nya setelah makan. Dengan demikian ia akan merasakan kehadiran Ilahi pada waktu memenuhi keinginan-keinginan fisiknya. Hal ini penting artinya karena Islam menghendaki perpaduan nilai-nilai hidup material dan spiritual yang berbahagia. ${ }^{45}$ Firman Allah dalam surat Thaha ayat 81 .

\footnotetext{
${ }^{43}$ Ibid. hlm. 399.

${ }^{44}$ Zamakhsyari Abdul Majid, "Ekonomi..., hlm. 255.

${ }^{45}$ Abdul Hamid, "Teori..., hlm. 210.
} 


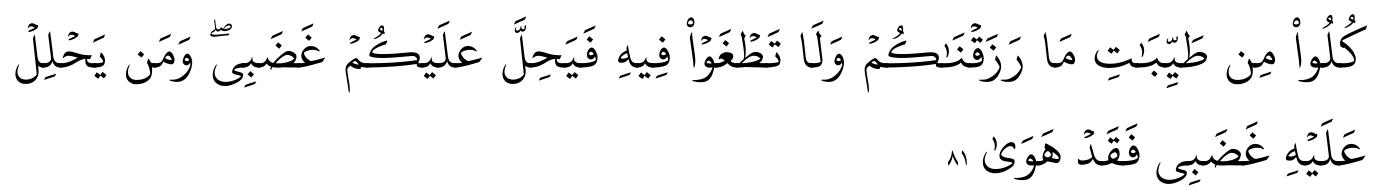

"Makanlah di antara rezeki yang baik yang telah Kami berikan kepadamu, dan janganlah melampaui batas padanya, yang menyebabkan kemurkaan-Ku menimpamu. Dan barangsiapa ditimpa oleh kemurkaan-Ku, maka sesungguhnya binasalah ia."

Makanlah rezeki dari sebagian yang baik yang telah Kami anugerahkan kepada kamu, dan janganlah melampaui batas padanya dengan melanggar tuntutan-Ku menyangkut cara perolehan dan penggunaannya, yang bila itu terjadi akan menyebabkan kemurkaan-Ku, maka sesungguhnya ia telah melucur jatuh ke tingkat bawah dari siksa neraka. Dan sesungguhnya Allah maha pengampun bagi hambaNya. ${ }^{46}$ Sebagai manusia kita juga menyadari bahwa sesungguhnya Allah-lah yang memberi kita makan dan minum. Seperti firmanNya dalam surat As-Syuara ayat 79.

Adapun hal-hal penting dalam berkonsumsi dengan prinsip moralitas yang perlu diperhatikan adalah sebagai berikut ${ }^{47}$ :

a. Umat, sesunguhnya saling keterkaitan dan saling sepenanggungan merupakan salah satu ciri dasar umat islam, baik individu maupun kelompok. Salah satu konsekwensi keimanan tersebut adalah bahwa konsumen muslim memperhatikan kondisi umatnya, sehingga dia tidak memperluas kualitas dan kuantitas konsumsi pribadinya, sementara kaum muslimin terutama tetangganya tidak mendapatkan kebutuhan-kebutuhan primer mereka.

b. Keteladanan, Umar Radiyallahu Anhu, selalu melakukan pengawasan perilaku konsumsi terhadap para individu yang

${ }^{46} \mathrm{M}$ Quraisy Shihab, Tafsir Al-Misbah Pesan, Kesan dan Keserasian al-Qur'an, (Jakarta: Lentera Hati, 2002) volume 8. hlm 345.

${ }^{47}$ Rahmat Ilyas, "Etika..., hlm. 158-159. 
menjadi panutan umat agar tidak menyelewengkan pola konsumsi mereka, sehingga terjadi penyelewengan dalam umat karena mengikuti mereka. Dan beliau melarang orang-orang yang menjadi teladan tersebut terhadap apa yang tidak beliau larang terhadap selain mereka.

c. Tidak membahayakan orang lain, setiap muslim wajib menjauhi perilaku konsumtif yang mendatangkan mudharat terhadap orang lain, baik secara langsung maupun tidak, terlebih jika bermudharat bagi orang banyak.

\section{Skema Pemikiran}

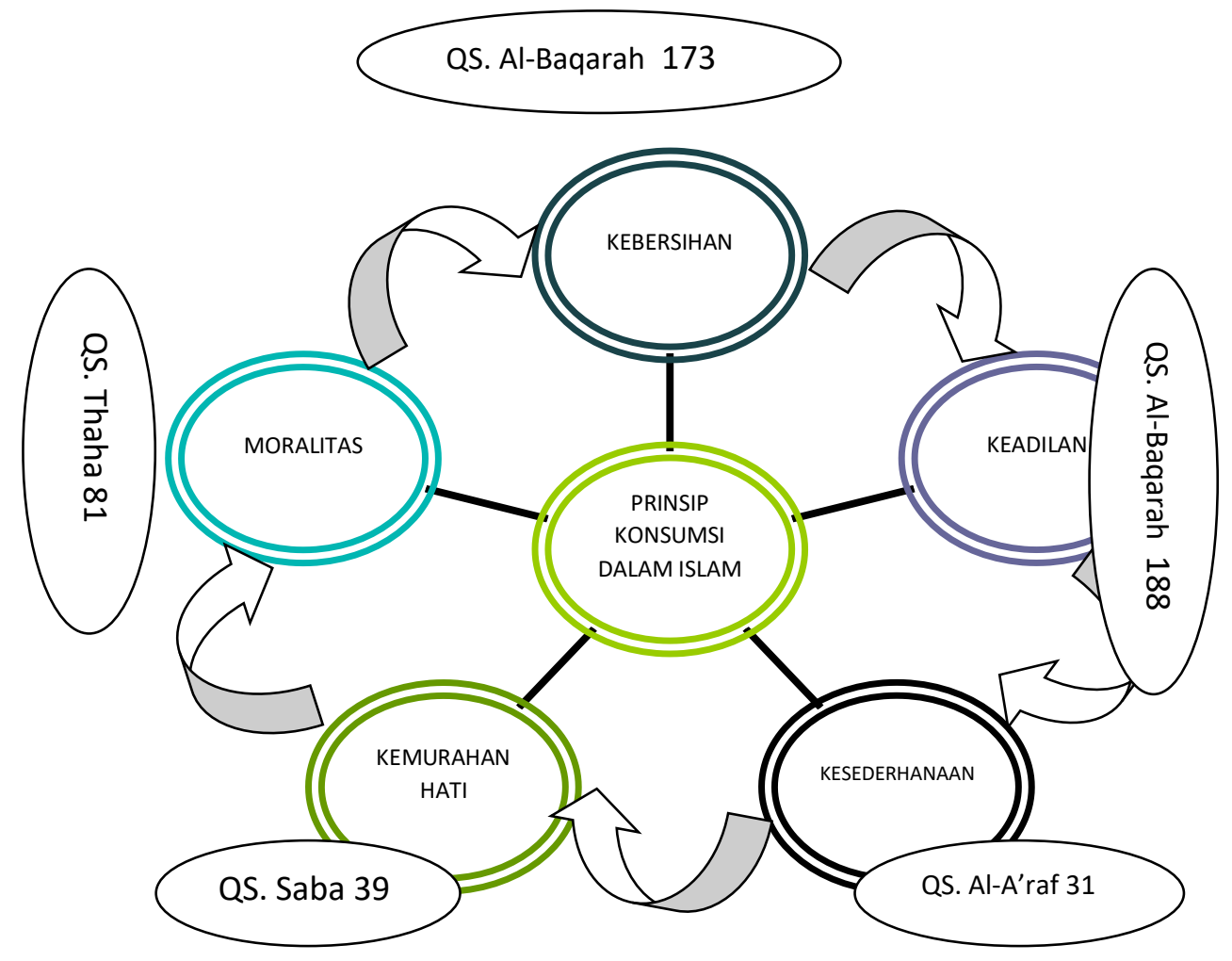

Dari pengambaran pola pikir penulis di atas, dapat diterangkan bahwa prinsip konsumsi yang dirumuskan sebagai $4 \mathrm{~K}+1 \mathrm{M}$ terdiri dari prinsip kebersihan, keadilan, kesederhanaan, kemurahan hati, dan 
moralitas. Prinsip-prinsip tersebut dalam pengaplikasiannya memiliki hubungan satu sama lainnya agar dalam berkonsumsi seorang muslim dapat memperoleh kemaslahatan. Dari permasing-masing prinsip ada ayat Al-Qur'an yang menjelaskannya, penulis hanya mengambil satu ayat permasing-masing prinsip yang dijelaskan menggunakan tafsir AlMisbah dengan Pendekatan hermeneutik terutama dalam mengeksplorasi dan menafsirkan prinsip-prinsip Al-Qur'an dan Hadis mengenai prinsip konsumsi muslim dalam realitas yang dihadapi sekarang. Untuk mendukung pendekatan hermeneutik juga digunakan metode semantik. Metode ini diperlukan terutama dalam menganalis kata-kata kunci yang dimaksud dalam penelitian ini. Adapun kata kunci dari artikel ini adalah Prinsip, 4k+1M, Konsumsi Perspektif Islam.

\section{Kesimpulan}

Sejak manusia mengenal hidup bergaul, tumbuhlah suatu masalah yang harus dipecahkan bersama-sama, yaitu bagaimana setiap manusia memenuhi kebutuhan mereka masing-masing, karena kebutuhan seseorang tidak mungkin dapat dipenuhi oleh dirinya sendiri. Makin luas pergaulan mereka, makin bertambah kuatlah ketergantungan antara satu sama yang lain untuk memenuhi kebutuhan itu.

Islam adalah agama yang ajarannya mengatur segenap prilaku manusia dalam memenuhi kebutuhan hidupnya. Demikian pula dalam masalah konsumsi, Islam mengatur bagaimana manusia dapat melakukan kegiatankegiatan konsumsi yang membawa manusia memperoleh kemashlahatan hidupnya.

Dalam ekonomi Islam konsumsi dikendalikan oleh lima prinsip dasar yang mana dapat dijadikan suatu pernyataan fundamental atau kebenaran umum maupun individual yang dijadikan oleh seseorang/ kelompok sebagai 
Prinsip Konsumsi 4k + 1m Dalam Perspektif Islam

sebuah pedoman untuk berpikir atau bertindak. diantaranya adalah Prinsip Keadilan, Prinsip Kebersihan, Prinsip Kesederhanaan, Prinsip Kemurahan Hati Dan Prinsip Moralitas. 


\section{DAFTAR PUSTAKA}

Ernawati, Ritta Setiyati., 2017, “Wawasan Qur'an Tentang Ekonomi (Tinjauan Studi Penafsiran Tematik Al-Quran)" Jurnal Ekonomi Volume 8 Nomor 2, November 2017.

Fauroni, Lukman., Tafsir Ayat-Ayat Tentang Konsumsi (Aplikasi Tafsir Ekonomi Al-Qur'an).

2006, Etika Bisnis Dalam Al-Qur'an, Yogyakarta: Pustaka Pesantren.

Hamid, Abdul., 2018, “Teori Konsumsi Islam Dalam Peningkatan Ekonomi Umat", J-Ebis Vol. 3 No. 2 Juni 2018.

Harahap, Isnaini, dkk., 2015, Hadis Hadis Ekonomi, Jakarta: Kharisma Putra Utama.

https://id.wikipedia.org/wiki/Prinsip dikutip pada hari Jum'at tanggal 5 April 2019 jam 15;30 WIB.

Ilyas, Rahmat., 2016., "Etika Konsumsi Dan Kesejahteraan Dalam Perspektif Ekonomi Islam", At-Tawassuth, Vol. 1, No. 1, 2016.

Majid, Zamakhsyari Abdul., 2016, “Ekonomi Dalam Perspektif Alquran”, Ahkam: Vol. XVI, No. 2, Juli 2016.

Qardawi, Yusuf., 2011, Halal Haram Dalam Islam, Solo: PT Era Adicitra Intermedia.

Rahman, Afzalur., 1995, Doktrin Ekonomi Islam Jilid II, Yogyakarta: PT. Verisia Yogya Grafika.

Rahman, Aulia., Muh Fitrah, 2018, "Perilaku Konsumsi Masyarakat Dalam Perspektif Islam Di Kelurahan Barombong Kota Makassar", Laa Maisyir: Jurnal Ekonomi Islam 5.1. (2018).

Shihab, M Quraisy., 2002, Tafsir Al-Misbah Pesan, Kesan dan Keserasian al-Qur'an, Jakarta: Lentera Hati, volume 1. 
Prinsip Konsumsi 4k + 1m Dalam Perspektif Islam

2002, Tafsir Al-Misbah Pesan, Kesan dan Keserasian al-Qur'an, Jakarta: Lentera Hati, volume 5.

2002, Tafsir Al-Misbah Pesan, Kesan dan Keserasian al-Qur'an, Jakarta: Lentera Hati, volume 8.

Yuniarti, Vinna Sri., 2016, Ekonomi Mikro Syariah, Bandung: CV Pustaka Setia. 